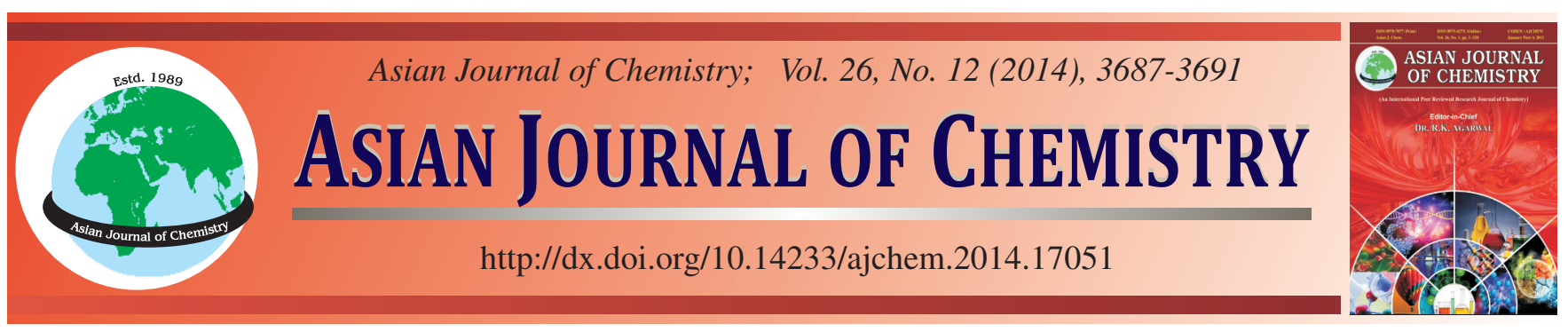

\title{
Proteomics and its Related Biological Activity of Jatropha tanjorensis Ellis \& Saroja: An Ethnomedicinal Plant $\dagger$
}

\author{
K.P. Arun ${ }^{1, *}$, P. BalajI ${ }^{1}$, P.R. Sivashankari ${ }^{2}$, C. David Raj ${ }^{1}$ and P. Brindha ${ }^{1}$
}

${ }^{1}$ Centre for Advanced Research in Indian System of Medicine, SASTRA University, Thanjavur-613 401, India

${ }^{2}$ School of Chemical and Biotechnology, SASTRA University, Thanjavur-613 401, India

*Corresponding author: E-mail: arun@ carism.sastra.edu

Published online: 5 June 2014;

AJC-15325

\begin{abstract}
Traditionally Jatropha tanjorensis is being used as an alternative medicine and the phytochemical investigation of this plant has proved that the leaves contain antioxidant, anti-hyperglycaemic and antiinflammatory bio molecules. The crude protein extract was analyzed by non-reducing native-PAGE, which showed three prominent protein bands with molecular weight of about 78.6, 67.8 and 43.3 KDa. Further, 2D studies and mass spectrometric (MS) analysis were done separately. Protein separations were examined using pH 3-10 nonlinear IEF strip. Totally 89 protein spots were detected differing in their $p$ I values, suggesting a possible difference in their electrostatic charge. In regard to mass spectrometric analysis coupled with in-gel digestions were performed for 5 major protein spots using trypsin and were identified through peptide mass fingerprint of selected peptides in UHPLC-ESI-Quad-TOF and MALDI-TOF mass spectrometer. Proteomic approach lead to the identification of major proteins from J. tanjorensis. Among various proteins, redox enzymes and DNA binding proteins were found to be most abundantly extracted proteins. These classes of proteins are known for their antioxidant, antimicrobial and anticancer activities and hence the extracted proteins were evaluated for their biological activities with a view to develop a novel therapeutic agent. The proteins extract revealed potent antioxidant and antimicrobial activities, when compared to standards. It showed $\mathrm{IC}_{50}$ value as $173 \mu \mathrm{g} / \mathrm{mL}$ for DPPH scavenging, LPO inhibition $(226.2 \mu \mathrm{g} / \mathrm{mL})$ and hydroxyl ion reducing assays $(269.5 \mu \mathrm{g} / \mathrm{mL})$. In antimicrobial studies it was effective against both gram positive and negative bacteria's such as $S$. aureus MTCC 96, S. aureus MTCC EI, P. aeruginosa MTCC 741, P. aeruginosa MTCC EI, B. subtilis MTCC 441 and E. coli MTCC 723 with MIC values ranging from 7.8-15.6 $\mu \mathrm{g} / \mathrm{mL}$ which are comparable to MIC values of standard antibiotics. Jatropha tanjorensis protein extract has also shown potent cytotoxicity against Ehrlich ascites carcinoma (EAC) with an $\mathrm{IC}_{50}$ of $49.9 \mu \mathrm{g} / \mathrm{mL}$. Present study scientifically proves the traditional usage of Jatropha tanjorensis as a health tonic and for the management of microbial infections.
\end{abstract}

Keywords: Jatropha tanjorensis, MS, 2DE, Antioxidant, MIC, Ehrlich ascites carcinoma.

\section{INTRODUCTION}

Jatropha tanjorensis (JT) commonly known as "Thanjavur kattamani" is used in Ethnomedicine for the treatment of hypertension, diabetes and as an antiseptic agent. Scientific advancements have lead to the exploration of many such plants chemically for its constituents and their impact in treating several types of diseases. As little attention has been devoted to understand the functional role of ethnomedicinally important plant proteins in relation to its therapeutic use and considering the potential advantage of using plant proteins as drugs (due to non-toxic nature), a through scientific research is attempted. Proteome analysis deals with determination of biological roles and functions of identified proteins ${ }^{1}$. However, the usage of Jatropha tanjorensis leaves has been scientifically proven for its therapeutic usage $\mathrm{e}^{2}$ and till now, protein analysis of Jatropha tanjorensis leaves have not yet been explored. In this study, proteins from Jatropha tanjorensis leaves were extracted, considering that this plant contains rich oil content. Furthermore, besides its high fat content in the leaves, its phenolic contents were also high ${ }^{3}$ which tend to obstruct the protein separation process ${ }^{4}$. In order to acquire a good quality and quantity of protein from Jatropha tanjorensis, acetone precipitation was performed during protein extraction. Proteomic approaches have brought huge possibilities to evaluate different functions of these proteins in various disease conditions. We investigated the proteome of Jatropha tanjorensis and its biological activity using antioxidant and antimicrobial assays. Further to this, cytotoxic assay was also performed on Ehrlich ascites carcinoma cells. Proteomic analyses of Jatropha tanjorensis leaves revealed the presence of biologically active proteins, most of which correspond to redox metabolism, storage 
proteins, carbohydrate metabolism and stress-related proteins. In this context, preliminary attempts have been made to investigate the proteome of $J$. tanjorensis using advanced proteomic tools to substantiate its ethnomedical claims and explore their possible potential implication in drug development.

\section{EXPERIMENTAL}

Jatropha tanjorensis fresh leaves were sourced from different locations in and around SASTRA University, Thanjavur during the month of October 2011 and identified and authenticated by comparing with the Herbarium samples deposited at Raphinet Herbarium, St. Joseph's College, Trichy, Tamil Nadu, India.

Protein extraction: Fresh plant leaves $(10 \mathrm{~g})$ were defatted with petroleum ether $60-80^{\circ} \mathrm{C}$ for $4 \mathrm{~h}$ and then dried, after which the plant material was homogenized with minimum amount of $1 x$ PBS in chill condition. This was filtered through pre-chilled filter paper and the collected homogenate was cleared off debris by centrifugation for $15 \mathrm{~min}$ at $12,000 \mathrm{~g}$ at $4{ }^{\circ} \mathrm{C}$. The supernatant obtained was concentrated using $70 \%$ acetone (protein precipitation). Subsequently, it was dialyzed against cold MilliQ water and kept for lyophilization.

2DE analysis: The protein samples containing $700 \mu \mathrm{g}$ total/ppt proteins, were resuspended as per the Hoefer lysis buffer (8 M urea, $20 \mathrm{mM}$ DTT, $2 \%$ CHAPS, $1 \%$ ampholytes giving $\mathrm{pH}$ 3-10 gradient) and was loaded onto IPG strip trough $(24 \mathrm{~cm})$, pH 3-10 non-linear gradient IPG strips (Serva) and was rehydrated at room temperature for $6 \mathrm{~h}$. This was then subjected to IEF in a Hoefer IEF 100 system according to the manufacturer's instruction. IEF configurations are as follows: $18 \mathrm{~h}$ at $50 \mathrm{~V}, 1 \mathrm{~h}$ at $1000 \mathrm{~V}$ gradient, $1 \mathrm{~h}$ at $10000 \mathrm{~V}$ gradient, $45000 \mathrm{Vh}$ followed by $1000 \mathrm{~V}$ for $1 \mathrm{~h}$ constant. After IEF, these strips were equilibrated in an equilibration solution I (6 M urea, $75 \mathrm{mM}$ Tris at $\mathrm{pH} 8.8,2 \% \mathrm{SDS}, 30 \%$ glycerol, $0.002 \%$ bromophenol blue) containing $1 \%$ DTT for $15 \mathrm{~min}$ followed by addition of equilibration solution II ( $3 \%$ iodoacetamide) and incubated for another $15 \mathrm{~min}$. Proteins were further separated in the second dimension through SDS polyacrylamide gels $(15 \%)$ at $150 \mathrm{~V}$ constant following Laemmli (1970) method $^{5}$. Electrophoresis process was made using $15 \%$ SDSPAGE gel run at a constant voltage of $150 \mathrm{~V}$. The gel was stained with silver staining solution and the gel image was captured using ChemiDoc XRS imaging system (Bio-Rad laboratories) and protein spots were identified using quantity one software (Bio-Rad laboratories).

In-gel digestion: In-gel digestion was carried out according to a method described by Shen et al. ${ }^{6}$. Briefly, each major protein spots were excised from the gel and washed with $25 \%$ $\mathrm{v} / \mathrm{v}$ methanol and $7 \% \mathrm{v} / \mathrm{v}$ acetic acid solution until clear background was obtained this was destained using $100 \mathrm{~mL}$ of $50 \mathrm{mM} \mathrm{NH} \mathrm{HCO}_{3}(50 \% \mathrm{v} / \mathrm{v}$ methanol) for $1 \mathrm{~h}$ at room temperature. $10 \mathrm{mM}$ DTT in $100 \mathrm{mM} \mathrm{NH} \mathrm{HCO}_{3}$ was added to each protein gel slices for reduction for $1 \mathrm{~h}$ and were incu-

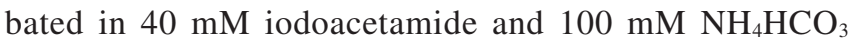
solution for $0.5 \mathrm{~h}$ at room temperature. Each gel slice was minced and rehydrated in $100 \mathrm{mM} \mathrm{NH}_{4} \mathrm{HCO}_{3}$ containing $5 \mathrm{ng}$ trypsin (trypsin, modified, sequencing grade) overnight at $37^{\circ} \mathrm{C}$. Following trypsin digestion, each protein spot peptides were collected and were extracted with $0.1 \%$ TFA $(50 \% \mathrm{v} / \mathrm{v}$ acetonitrile). After each extraction, resultant solutions were centrifuged at $10000 \mathrm{~g}$ for $5 \mathrm{~min}$, supernatants were collected and combined followed by freeze drying. Each dried protein peptides were stored at $20^{\circ} \mathrm{C}$ until MALDI analysis.

Mass spectrometry analysis: MALDI-TOF analyses carried out as per reported method ${ }^{7}$. Briefly, an aliquot of 1 $\mu \mathrm{L}$ sample and $1 \mu \mathrm{L}$ saturated HCCA matrix solution were mixed and spotted on MTP 384 steel target and dried. Mass spectra were obtained on ultraflex MALDI TOF/TOF equipped with pulse nitrogen laser $(337 \mathrm{~nm} ; 50 \mathrm{~Hz})$ in reflectron positive mode.

Mascot protein identification: Tandem mass spectral data were used for database searching through Mascot program (Matrix Science Ltd., version 2.1) using 3.2 version of Bruker BioTools interface. Identification of proteins was made through Mascot Protein Search Database (MSDB) search engine (www.matrixscience.com) keeping viridiplantae (green plants) taxonomy. Trypsin was opted as proteolytic enzyme with carboxymethyl (C) as fixed modification and oxidation (M) as variable modification.

\section{Bioactivity}

Hydroxyl radical scavenging assay: This was performed using standard method ${ }^{8}$. Test was carried out in triplicates. BHT was used as positive control. The $\%$ inhibition was calculated by comparing optical density of test with positive control and negative control.

Scavenging activity of DPPH free radical: This activity was assayed to determine the antioxidant potential of the investigated plant protein as previously described ${ }^{9}$. Activity was calculated as follows: $\%$ of radical scavenging activity = $100-[$ (each value - pos control $) /$ neg control $] \times 100$.

Lipid peroxidation inhibition assay: Inhibition of lipid peroxidation was performed as per the method of Kizil et al. ${ }^{10}$. RBCs were separated from anticoagulated blood and diluted to $1 \times 10^{6}$ cells $/ \mathrm{mL}$ using phosphate buffer $(50 \mathrm{mM}, 120 \mathrm{mM}$ $\mathrm{KCl}, \mathrm{pH}$ 7.4). A $100 \mu \mathrm{L}$ aliquot of these homogenous RBCs were mixed with plant protein of various concentrations (10$1000 \mu \mathrm{g} / \mathrm{mL}$ ). BHT was used as standard.

Proteolytic activity: Protease activity assay was performed using standard method ${ }^{11} .2 \%$ fat-free casein protein was used as substrate. To $0.5 \mathrm{~mL}$ of substrate, various concentrations $(0-1000 \mu \mathrm{g})$ of $J$. tanjorensis crude protein sample were incubated for $2 \mathrm{~h}$ at $37^{\circ} \mathrm{C}$. Assay was terminated by the addition of $0.44 \mathrm{M}$ TCA and kept for incubation at room temperature for $0.5 \mathrm{~h}$. Resulted solution was centrifuged to collect supernatant. To the supernatant collected, Lowry's reagent was added. Absorbance was read at $660 \mathrm{~nm}$ after $10 \mathrm{~min}$.

Hemolytic activity: Direct hemolysis was performed as described by Boman and Kaletta ${ }^{11}$. HRBC (blood group A) was collected from a freshly collected anticoagulated blood sample. Various conc. (0-1000 $\mu \mathrm{g} / \mathrm{mL})$ of J. tanjorensis protein samples were added to $1 \% \mathrm{HRBC}$ in $1 \mathrm{x}$ PBS for $0.5 \mathrm{~h}$ at $37^{\circ} \mathrm{C}$. The amount of hemoglobin released was measured spectrophotometrically at $540 \mathrm{~nm}$.

Antimicrobial activity: Pure cultures of Staphylococcus aureus MTCC 96, Staphylococcus aureus MTCC 3160, Pseudomonas aeruginosa MTCC 741, Pseudomonas 
aeruginosa MTCC 1688, Bacillus subtilis MTCC 441, Escherichia coli MTCC 723 were obtained from Microbial type culture collection, MTCC, Chandigarh, India. Nutrient agar, Nutrient broth, Muller Hinton Agar, Muller Hinton broth were obtained from Hi Media Private Ltd., Mumbai, India.

The pure cultures obtained were revived and maintained in nutrient agar at $37^{\circ} \mathrm{C}$. The microorganisms were cultured in nutrient broth at $37^{\circ} \mathrm{C}$ overnight; the resulting suspensions were fixed to $0.5 \mathrm{McFarland}$ standards, this is approximately equivalent to $1.5 \times 10^{8} \mathrm{CFU} / \mathrm{mL}$.

Agar well diffusion method: Antibacterial activities of the proteins were determined by the formation of inhibition zone in Muller Hinton agar and compared with standard antibiotics. Briefly, Muller Hinton agar plates $(25 \mathrm{~mL})$ were prepared and the appropriate bacterial cultures were inoculated onto the surface of agar through sterile cotton swabs by spread plate method. Wells of $6 \mathrm{~mm}$ diameter were bored on the inoculated plates using sterile cork borer. $100 \mu \mathrm{L}$ of samples were loaded to the wells, with concentration ranging from 250 , 500, 750 and $1000 \mu \mathrm{g} / 100 \mu \mathrm{L}$. Ciprofloxacin hydrochloride $(0.4 \mu \mathrm{g} / 100 \mu \mathrm{L})$ was used as standard antibiotic and 1x PBS ( $\mathrm{pH}$ 7.4) was used as control. For each sample duplicates were done. Plates were incubated at $37^{\circ} \mathrm{C}$ for $24 \mathrm{~h}$. Resulting zones of inhibition formed around the wells were measured.

Minimum inhibitory concentration (MIC): MIC of the protein samples were evaluated by broth micro-dilution method ${ }^{13}$. Briefly, two fold dilutions of the samples were prepared with Muller Hinton broth, that yields concentration ranging from $0.009,0.019,0.039,0.07,0.15,0.3,0.6,1.25,2.5,5 \mathrm{mg} / \mathrm{mL}$ in a 96 well plate. Inoculated and non-inoculated well devoid of protein sample were used as positive and negative control, respectively. The least concentration detected with no visible bacterial growth has been considered as the MIC of the sample.

Cytotoxicity assay: Cytotoxicity was performed as per the method of Mosmann ${ }^{13}$. Ehrlich ascites carcinoma cells were suspended in RPMI 1640 complete medium $\left(1 \times 10^{6}\right.$ cells $/ \mathrm{mL})$ and each protein samples $(0.005-2.5 \mathrm{mg} / \mathrm{mL})$ were added and incubated for $24 \mathrm{~h}$. MTT reagent solution was then added and incubated again at $37{ }^{\circ} \mathrm{C}$ for $3 \mathrm{~h}$. The coloured crystals generated were dissolved using DMSO and then read out at $530 \mathrm{~nm}$. Percentage inhibition was then calculated.

Statistical analysis: For each assay, all values were normalized to control values and $\mathrm{IC}_{50}$ were calculated using Prism 5.1 Program at non-linear regression.

\section{RESULTS AND DISCUSSION}

Proteins belonging to different classes were identified by searching the mass spectrometry data through Mascot online protein search database. As these classes of proteins were known to be involved in antioxidant, antimicrobial and anticancer activities, the extracted proteins were evaluated for their biological activities with a view to develop it as a therapeutic agent.

2D-PAGE is the common method of choice for proteomic analysis followed by spot excision and MS analysis. This study presents substantial possibility in scientifically evaluating the indigenous plant resources for the isolation of therapeutically potential proteins. J. tanjorensis proteins which include DNA Binding proteins and other nuclear proteins identified using
MALDI-TOF may provide a remarkable opportunity to develop drugs that would be effective against vast number of pathogenic microbes and effective against cancerous cells that in turn improves the quality of life.

2DE revealed more than 30 intense spots out of 89 identified spots (Fig. 1). These major spots were excised and were used for pre-processing followed by MALDI-TOF analysis.

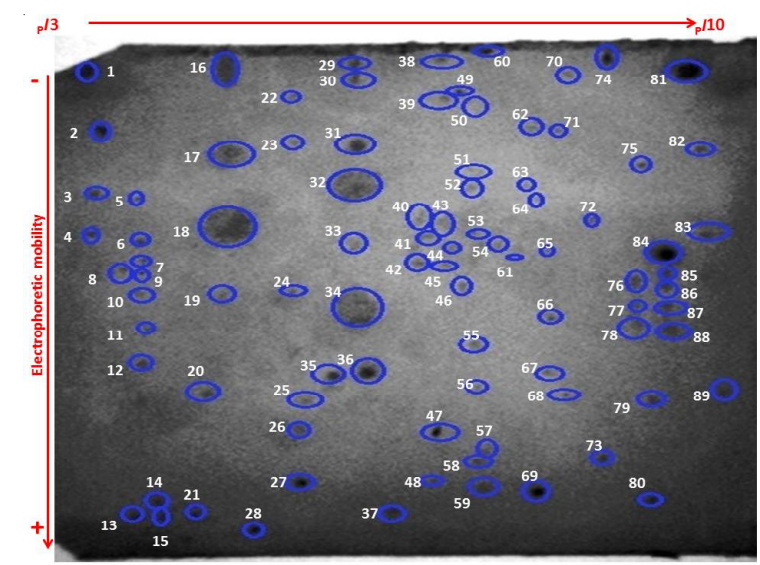

Fig. 1. 2DE pattern of J. tanjorensis proteins. Proteins spots are encircled and marked

MASCOT peptide mass fingerprinting search tool was used to identify various proteins using SwissProt database. 17 major proteins were identified. Out of these, spots 1, 18, 49 and 84 showed significant matches to major cancer related proteins DNA topoisomease, zinc finger $\mathrm{CCCH}$ domain, ATP dependent RNA helicase and actin-1 (Table-1).

Protein related to redox reactions were also identified as an abundant protein in the leaves of J. tanjorensis. In plants, the oxidase families carry multiple functions, such as oxidation of toxic reductants, biosynthesis and degradation of lignin in cell walls, defensive responses to wounding and against pathogen or insect and in auxin catabolism ${ }^{14}$. Another valuable proteins identified in the leaves of J. tanjorensis were Nuclear protein Ran-binding protein 1 (spot 69), DNA directed RNA polymerase (spot 36), RNA pseudourine repeat protein (spot 32) and RNA methyl transferase (spot 81).

Other proteins identified in J. tanjorensis belongs to Ribulose 1,5-bisphosphate carboxylase (spot 40) and peroxisomal (S)-2-hydroxy-acid oxidase (spot 34) which help in photorespiration and play its catalytic role in the oxidation of glycolate to glyoxylate and in the conversion of glyoxylate to oxalate through oxidation ${ }^{15}$.

In addition, spot 16 corresponding to pleutropic drug resistance protein is known for its antifungal action and is abundant during slat stress. Major identified proteins in the present study are given in Table-1. Mascot score for most of the proteins were greater than 30 which indicates approximate homology with a significance level of $p>0.05$. Although, medicinal property of J. tanjorensis has been reported in previous studies which were focusing mainly on the secondary metabolites extracted from this plant. Presently there is no scientific report on the primary metabolites of this plant (J.tanjorensis), which may contribute towards better medicinal and industrial usage of Jatropha tanjorensis. Proteins identified in the present study could be clustered into 8 functional groups (Fig. 2). 


\begin{tabular}{ccccc}
\hline \multicolumn{5}{c}{ DESCRIPTION OF VARIOUS PROTEINS IDENTIFIED USING MASCOT SEARCH } \\
\hline Spot No. & Biological process & Identified protein & Mascot score & Theoretical Mr \\
\hline 69 & Stress response & Ran-binding protein 1 & 91 & 25814 \\
36 & Stress response & DNA Directed RNA polymerase & 57 & 38985 \\
34 & Stress response & Peroxisomal Oxidase & 56 & 40621 \\
84 & Stress response & Actin -1 & 58 & 42014 \\
33 & Stress response & Probable protein arginine N-methyltransferase & 81 & 43823 \\
18 & Stress response & Zinc finger CCCH domain & 58 & 50026 \\
43 & Stress response & Aspartic proteinase like protein 2536 \\
40 & Energy metabolism & RuBiSCO & 55 & 5253 \\
32 & Energy metabolism & RNA pseudourine synthase & 55 & 52875 \\
51 & Stress response & Oxidase & 80 & 53702 \\
17 & Cytoskeleton constructing & Pentatricopeptide repeat protein & 58 & 56369 \\
31 & Energy metabolism & Maturase K & 69 & 57570 \\
2 & Cytoskeleton constructing & IAA synthase & 69 & 59771 \\
49 & Stress response & ATP dependent RNA Helicase & 55 & 68122 \\
1 & Stress response & DNA topoisomerase & 59 & 81908 \\
81 & Hydrogen peroxide & RNA methyl transferase & 68 & 103248 \\
16 & Salt stress/antifungal & Pleutropic drug resistance protein & 42 & 105643 \\
& & & 42 & 163887 \\
\hline
\end{tabular}

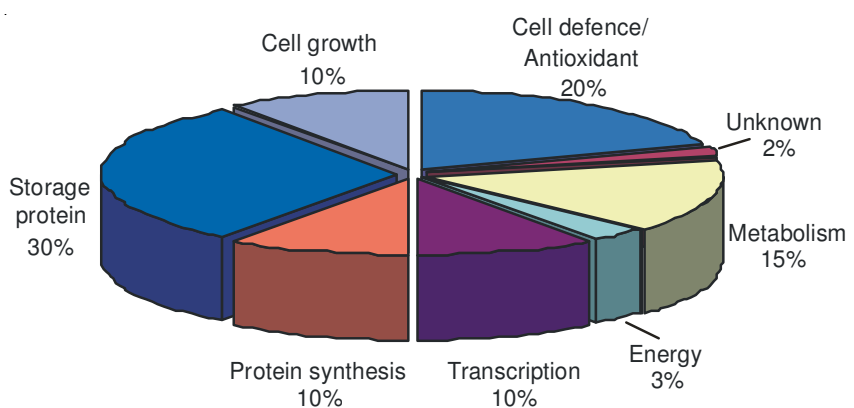

Fig. 2. Distribution of protein identified according to their major function in plant

Identification followed by bio-activity studies on plant proteins against various pathogenic microorganisms has attracted many researchers. Activity like antiproliferation is related with treating cancer. Scavenging of free radicals during oxidative stress has been implicated in treating human diseases like degenerative disorders and microbial pathogenesis. Present work has enlightened the vital role of Jatropha tanjorensis as an ethnomedicine. LPO inhibition (Fig. 3), $\mathrm{OH}^{-}$reducing (Fig. 4) and DPPH scavenging (Fig. 5) ability has been identified as playing major roles in protecting cells against damage due to free radicals, radiation, carcinogens and xeno-biotics. Present work revealed that protein extract of Jatropha tanjorensis leaves possess significant anti-oxidant, antibacterial (against both gram stains bacterial species of different strains) activities

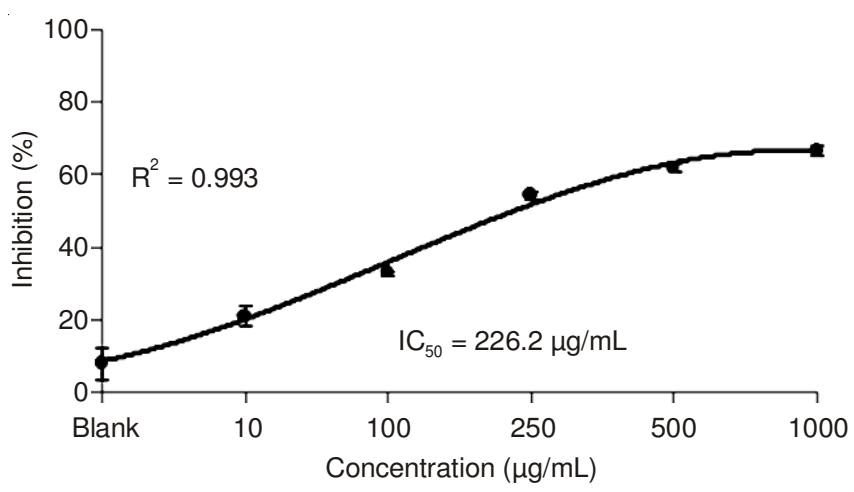

Fig. 3. LPO inhibition activity of $J$. tanjorensis

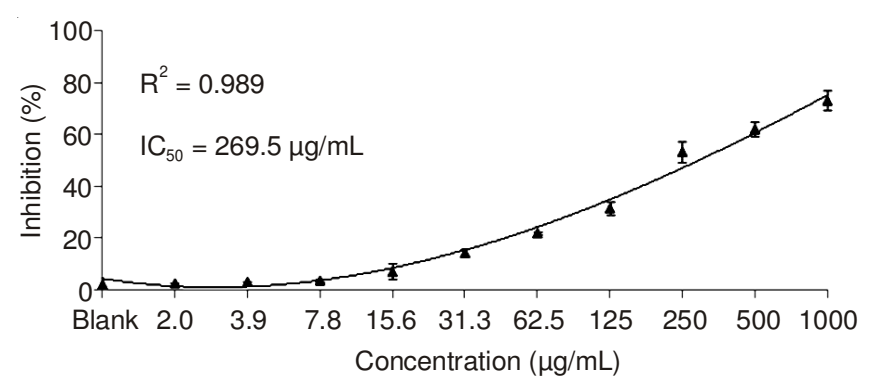

Fig. 4. Hydroxyl free radical inhibition activity of $J$. tanjorensis

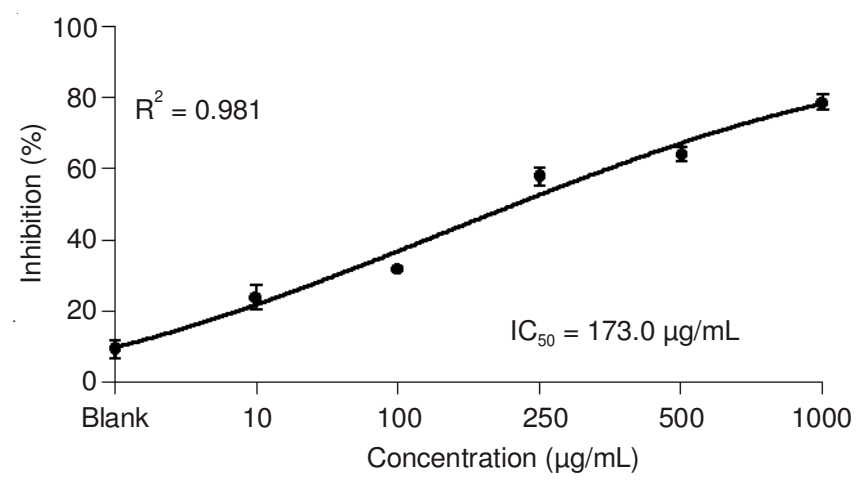

Fig. 5. DPPH free radical scavenging activity of $J$. tanjorensis

(Table-2, Fig. 6). Proteolytic (Fig. 7) and hemolytic (Fig. 8) activity were observed at higher concentration which suggest its non-toxic effect on normal physiological blood parameters. J. tanjorensis leaves protein extract has shown a potent anticancer potential against Ehrlich ascites carcinoma cells (Fig. 9).

\section{Conclusion}

The proteomic approach is attempted in the present work for J. tanjorensis to investigate the functional role of proteins and their therapeutic applications. Data obtained from the experimental work on in vitro studies such as antioxidant, antimicrobial and anticancer potentials provided substantial scientific evidences to support its ethnomedicinal claims against various patho-physiological conditions. This is the first report, wherein the advanced proteomic approaches have been explored to substantiate traditional claims of the medicinally important 


\begin{tabular}{|c|c|c|c|}
\hline \multicolumn{4}{|c|}{$\begin{array}{c}\text { TABLE-2 } \\
\text { ANTIBACTERIAL ACTIVITY OF J. tanjorensis TOTAL PROTEIN EXTRACT }\end{array}$} \\
\hline \multirow{2}{*}{ Microorganisms } & \multicolumn{2}{|c|}{ Zone of inhibition $(\mathrm{mm})$} & \multirow{2}{*}{$\frac{\text { Average MIC }(\mu \mathrm{g} / 100 \mu \mathrm{L})}{\mathrm{ppt}}$} \\
\hline & Total & CIP & \\
\hline S. aureus MTCC 96 & $25.12 \pm 3.25$ & $21.87 \pm 2.5$ & $7.8 \pm 0.4$ \\
\hline S. aureus MTCC EI & $22.5 \pm 1.58$ & $18.5 \pm 1.1$ & $7.8 \pm 0.3$ \\
\hline P. aeruginosa MTCC 741 & $22.87 \pm 3.7$ & $15.5 \pm 1.3$ & $7.8 \pm 1.0$ \\
\hline P. Aeruginosa MTCC EI & $27.75 \pm 3$ & $20.25 \pm 0.5$ & $7.8 \pm 1.1$ \\
\hline B. subtilis MTCC 441 & $19.62 \pm 2.3$ & $23.75 \pm 0.9$ & $7.8 \pm 0.7$ \\
\hline E. coli $\mathrm{MTCC} 723$ & $27.25 \pm 3.23$ & $25.25 \pm 2.3$ & $7.8 \pm 0.2$ \\
\hline
\end{tabular}

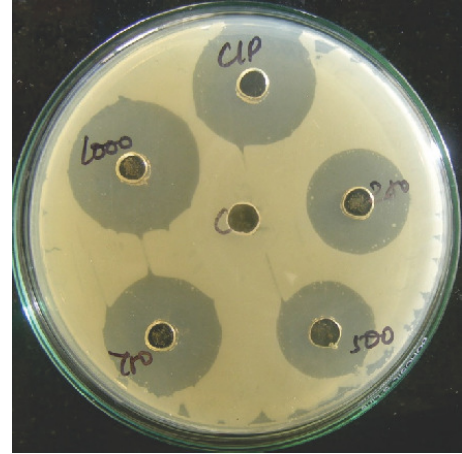

Fig. 6. Representative image of agar well diffusion assay. S. aureus MTCC 96 susceptibility towards J. tanjorensis

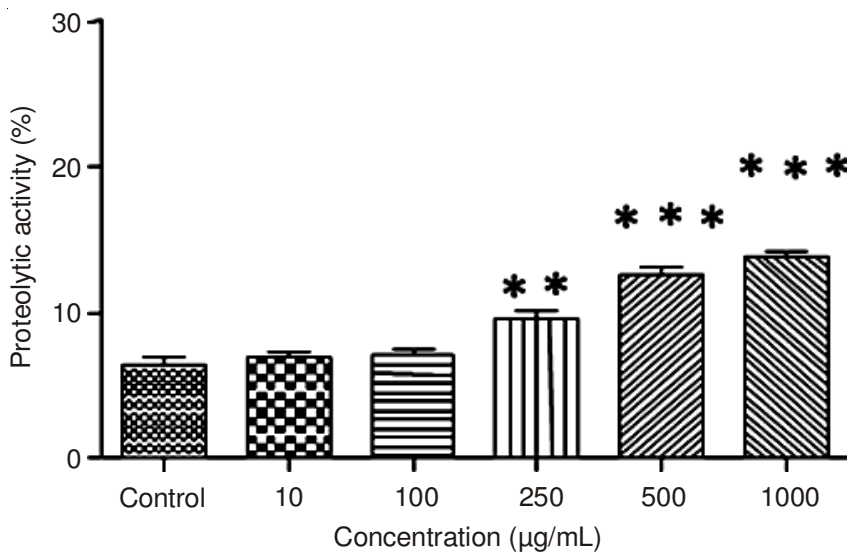

Fig. 7. Proteolytic activity of J. tanjorensis leaves total protein

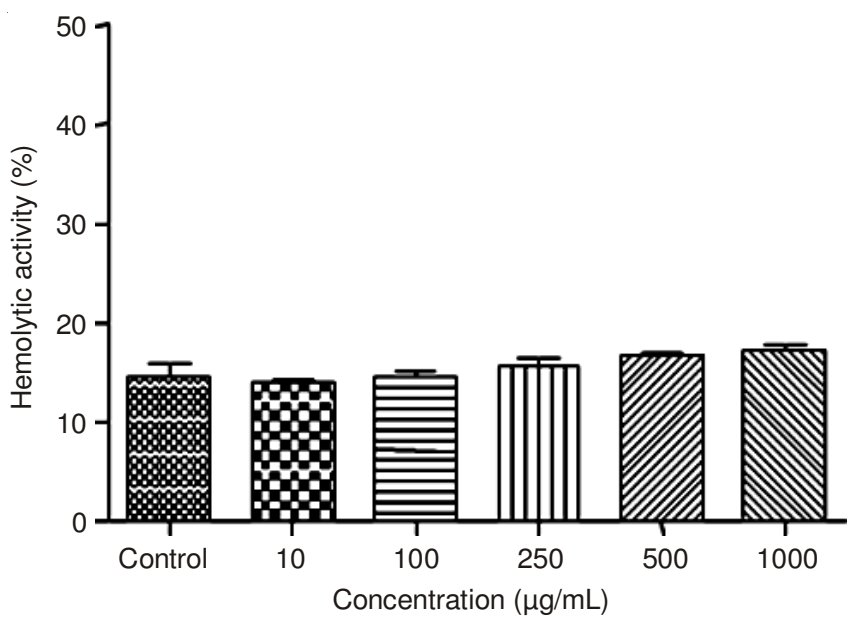

Fig. 8. Hemolytic activity of $J$. tanjorensis leaves total protein

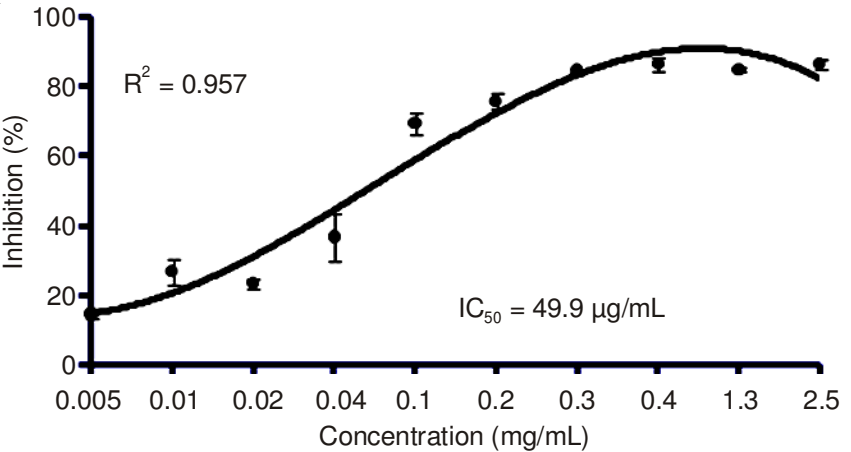

Fig. 9. Anticancer activity of J. tanjorensis leaves total protein against EAC

plants and subsequently contribute towards the development of drugs for the better healthcare of human society.

\section{ACKNOWLEDGEMENTS}

The authors gratefully acknowledged the Hon'ble Vice Chancellor, SASTRA University, Thanjavur for providing necessary infrastructure and funding provided by DST (VI-D\&P/ 267/08-09/TDT) is also duely acknowledged.

\section{REFERENCES}

1. S.M. Lin, M.J. Campa, M.Z. Wang, B. Howard, M.C. Fitzgerald and E.F. Patz Jr., Use of Mixture models in MALDI-TOF Proteomic Data for Peak Registration, In Proceedings of the CBGI (2003).

2. K.P. Arun and P. Brindha, Int. J. Pharm. Pharm. Sci., 4 (Suppl 2), 136 (2012).

3. K.P. Arun, N. Ravichandran, R. Vajrai and P. Brindha, Int. J. Pharm. Pharm. Sci., 4 (Suppl 2), 139 (2012).

4. T. Isaacson, C.M.B. Damasceno, R.S. Saravanan, Y. He, C. Catalá, M. Saladié and J.K.C. Rose, Nat. Protoc., 1, 769 (2006).

5. U.K. Laemmll, E. Mölbert, M. Showe and E. Kellenberger, J. Mol. Biol., 49, 99 (1970).

6. S. Shen, Y. Jing and T. Kuang, Proteomics, 3, 527 (2003).

7. O. Jensen, M. Wilm, A. Schevschenko and M. Mann, Methods in Molecular Biology: 2-D Proteome Analysis Protocols, 112 (in ed.: A.J. Link), Humana, Totowa, NJ, pp. 513-530 (1999).

8. B. Hazra, S. Biswas, N. Mandal BMC Complement. Altern. Med. 8, 63 (2008).

9. W. Brand-Williams, M.E. Cuvelier and C. Berset, LWT-Food Sci. Technol., 28, 25 (1995).

10. O. Kizil, Y. Akar, N. Saat, M. Kizil, and M. Yuksel, Revue Méd. Vét. 158, 529 (2007).

11. H.G. Boman and U. Kaletta, Biochim. Biophys. Acta, 24, 619 (1957).

12. J.M. Andrews, J. Antimicrob. Chemother, 48 (Suppl 1), 5 (2001).

13. T. Mosmann, J. Immunol. Methods, 65, 55 (1983).

14. K. Yoshida, P. Kaothien, T. Matusi, A. Kawaoka and A. Shinmyo Appl. Microbiol. Biotechnol., 60, 665 (2003).

15. J.M. Jones, J.C. Morrell and S.J. Gould, J. Biol. Chem., 275, 12590 (2000). 